\title{
Movements in the Foreign Exchange Value of the Dollar During the Current U.S. Expansion
}

\author{
DOUGLAS R. MUDD
}

F

OR seven quarters following the severe U.S. economic slowdown of 1973-75, the foreign exchange value of the dollar rose substantially, increasing by about 8 percent on a trademweighted basis. ${ }^{1}$ The dol. lar declined slightly only against the currencies of Canada and Switzerland. The most dramatic increases in the foreign exchange value of the dollar over 1975-76 were against the British pound and the Italian lira. In terms of the British pound, the value of the dollar rose by about 30 percent, and against the Italian lira the dollar rose by about 26 percent.

In contrast, since late 1976, the trade-weighted foreign exchange value of the dollar has fallen about 13 percent. Over the past seven quarters the value of the dollar has declined furthest against the Belgian franc (16.7 percent), German mark (20 percent), Japanese yen ( 52.5 percent), Dutch guilder ( 15.8 percent), and Swiss franc (46.1 percent). Since fourth quarter 1976 , the dollar has appreciated against only one of the world's nine other major industrial countries' currencies, increasing 13.3 percent against the Canadian dollar. ${ }^{2}$

Explanations of this sharp reversal in the trend of the dollar's foreign exchange value are often presented in terms of economic growth rate differentials. ${ }^{3} \mathrm{Al}$ though exchange rate movements can be influenced

The tradeweighted value of the dollar is a weighted average of the exchange rates between the dollar and the currencies of the United States' twenty major trading partners. The weights take account of the size of the trade flows and are derived from the International Monetary Fund's 'Multilateral Exchange Rate Model'. See Jacques $\mathrm{R}$. Artus and Rudolf $\mathrm{R}$. Rhomberg "A Multilateral Exchange Rate Model," International Monetary Fund Staff Papers (November 1973), pp. 591-611.

2The ten major industrial countries considered here are Belgium, Canada, France, Cermany, Italy, Japan, Netherlands, Switzerland, United Kingdom, and United States.

3 Of course, turning points in exchange rate movements differed between currencies. However, by the end of 1976 , the foreign exchange value of the dollar was, or began, falling against seven of the nine currencies considered here. by differences in economic growth rates, there is no reason to expect the foreign exchange value of the dollar to be dominated by the relatively rapid rate of U.S. economic growth. Rather, the current downward trend in the value of the dollar against most major currencies can be attributed primarily to differential excess money growth rates, as indicated by differential rates of inflation.*

\section{EXCHANGL RATES AND RCONOMTC GWOWTY DIFTERENTIATS}

A major factor sometimes cited as the cause of the recent decline in the foreign exchange value of the dolm lar is the vigorous growth of the U.S. economy relative to economic growth abroad. It has been asserted that as the U.S. economy expanded and national income increased, U.S. imports also rose; increased amounts of imported raw and intermediate materials were required to fuel the expanding U.S, economy, and rising incomes allowed consumers to increase their purchases of imported goods. At the same time, economic growth abroad has been generally sluggish, resulting in weak foreign demand (both business and consumer) for U.S. exports. Thus, the recent U.S. trade deficits (imports of goods and services have exceeded exports since early 1976) are viewed as having resulted from international growth differentials. These trade deficits, in turn, have been viewed as the primary cause of the downward slide in the foreign exchange value of the dollar. ${ }^{\bar{x}}$

\footnotetext{
4For a critical discussion of both hypotheses, see Herbert Stein, "The Mystery of the Declining Dollar" "The AEI Economist (American Enterprise Institute for Public Policy Research, September 1978).

5This argument ignores the possibility that both output growth and exchange rate changes have a common cause. Thus, autonomous increases in output should result in a depreciating currency. The argument also theoretically neglects the effects of international capital flows on exchange rates. There is not necessarily a causal link between a trade deficit and a depre-
} 


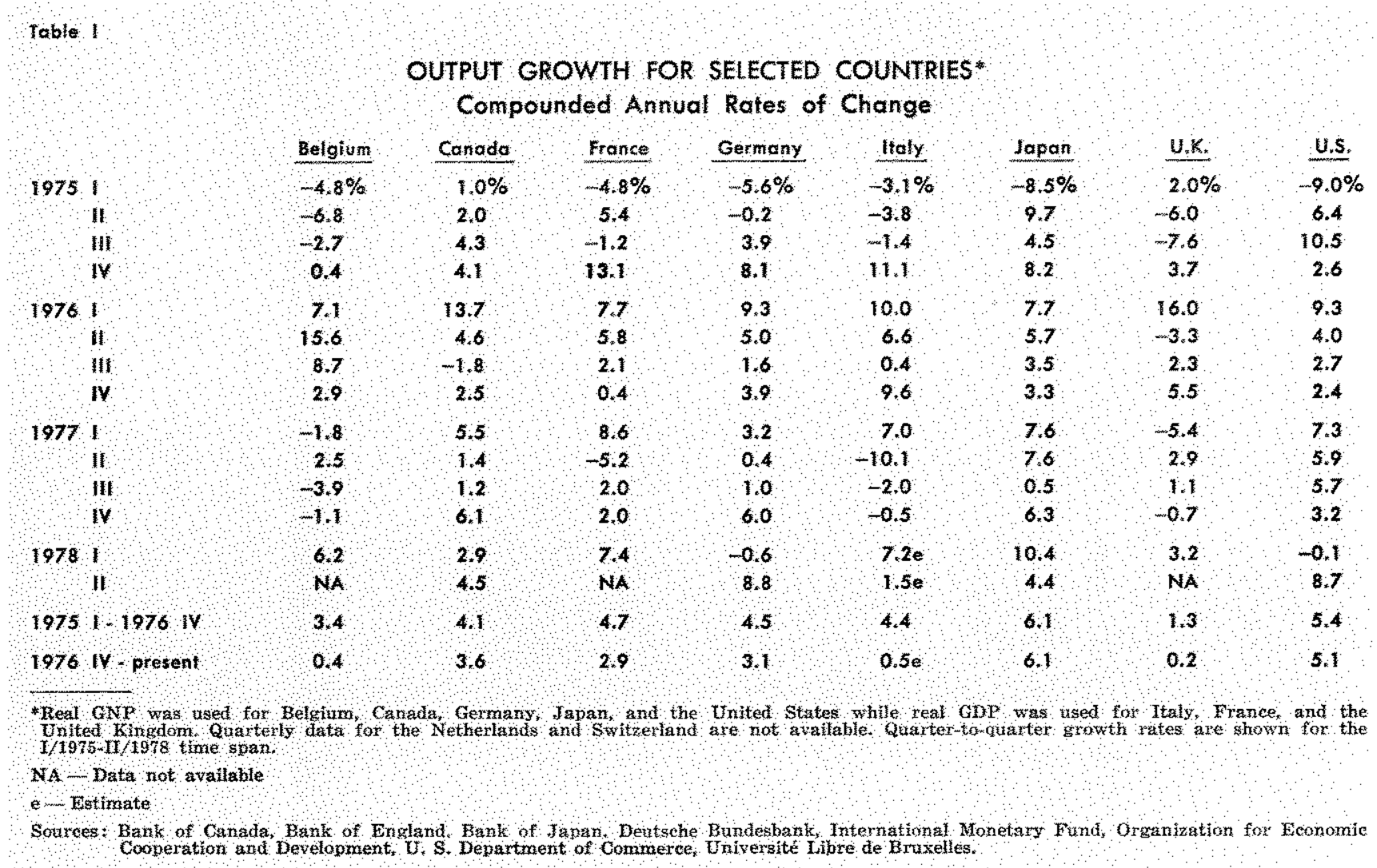

Table I shows output growth rates since 1975 in the United States and seven other industrialized economies. With the exception of Japan, U.S output growth over the 1975-76 period was stronger than output growth abroad. Yet, during that period, the trade-weighted foreign exchange value of the dollar rose.

Since late 1976, U.S. output growth has significantly accelerated relative to that of Belgium, France, Germany, Italy, and the United Kingdom. These five cases are consistent with the hypothesis that accelerating U.S. output growth relative to output growth abroad has caused the depreciation of the dollar.

Two cases presented in Table I contradict the argument that the foreign exchange value of the dollar should decrease (increase) when the U.S. economy expands more (less) rapidly than foreign econ-

ciating currency. For example, suppose an autonomots increase in U.S. output results from a technological innovation raising U.S. productivity. Even if a trade deficit results from this antononous increase in U.S. real income, capital inflows would be induced by the now higher real rate of retum on investment in the United States. There is no clear indication of the direction of change in the foreign exchange valie of the dollar. Therefore, higher real income growth in the United States than abroad does not, by itself, produce a depreciation of the dollar. omies. Although output growth in Japan since late 1976 has been substantially higher than in the United States, the value of the dollar in terms of the yen has fallen sharply and steadily. Further, although the value of the dollar in terms of the Canadian dollar has risen steadily since fourth quarter 1976 , U.S. output growth has been significantly faster than that in Canada. In the cases of both Japan and Canada (the United States' major trading partners), the view that recent movements in the foreign exchange value of the dollar have been in response to relatively more rapid economic growth in the United States than abroad is inconsistent with experience.

Thus, the hypothesis that exchange rates adjust to offset differences in economic growth is not clearly supported by the data. One limiting factor of this hypothesis is that it overlooks the importance of the impact of price differentials on international trade. For example, a U.S. resident might buy a new car if his real income increases. However, the choice between a domestically or foreign produced car depends upon, among other things, price differentials. The alternative hypothesis which incorporates these price effects explains movements in the foreign exchange value of the dollar over the $1975-78$ period better than 
the one which relies solely on differential rates of growth.

\section{AN ALTERNATIVE VIEW OF EXCHANGE RATE MOVEMENTS}

Another explanation of the primary cause of changes in the foreign exchange value of the dollar, which takes account of the association between exchange rates and inflation differentials, views exchange rate movements as essentially monetary phenomena, influenced strongly by such factors as money stock growth. ${ }^{\circ}$ Real factors, such as output growth, also are recognized as affecting exchange rate movements, but throngh monetary channels. ${ }^{t}$ When exchange rate movements are viewed within a monetary framework, changes in exchange rates reflect relative changes in excess money stock growth.

\section{Excess Money Stock Grown}

When the U.S. money stock, for example, is greater than the amount people desire to hold (given the prevaling levels of real income, interest rates, prices, and price expectations) an excess supply of money exists in the United States. As people attempt to reduce their holdings of money to desired levels, spending will rise. The increase in spending will be distributed anong goods and services, including both real and financial assets. If the increased spending is not accompanied by a similar rise in the supply of goods and services, U.S. prices will rise. Although price increases temporarily stimulate output growth, the long-tem pattern of output growth is limited by resource growth. If the U.S. money stock continues to exceed the amount of money people are willing to hold, total spending will continue rising, but only in the form of rising prices. In this framework, excess money stock growth is the primary cause of inflation, and changes in excess money stock growth are manifested by changes in the rate of inflation.

The dollar "price" of foreign currencies will also rise - that is, the toreign exchange value of the dollar will fall - if there is excess money growth in the United States, but not abroad. The rise in spending re-

"See Harry G. Johnson, "The Monetary Approach to Balanceof-Paynents Theory;" Further Esots in Monetan II conomict (Cambridge: Harvard Unversity Press, 1973), po. 229-49, and Jacob A. Frenkel, "A Monetary Approach to the Exchange Rate: Doctrinal Aspects and Empirical Evidence," Scandinavion Joumal of Economics, no. 2 (1976), pp. 200-24.

TSee Michael Mussa, "The Exchange Rate, the Balance of Pay. ments and Monetary and Fiscal Policy Under a Regime of Controlled Floating," Sandinatian Joumal of Econamics, no. 2 (1976) pp. $237-38$. sulting from an excess supply of money in the United States will result in increased purchases of both domestic and foreign goods, services, and financial assets. If there is no excess money growth abroad, foreign demand for U.S. goods, services and financial assets will not rise immediately. Similarly, if excess money stock growth exists both in the United States and abroad, but that growth in the U.S. is more rapid than abroad, then U.S. spending on foreign goods, services and financial assets will rise relative to foreign purchases in the United States. At the original exchange rate, the quantity of dollars which U.S. residents will want to spend to purchase foreign goods and services will be larger than the quantity of dollars foreigners want to buy to make purchases in the United States. As a result, the "prices" of foreign currencies in terms of the U.S. dollar will rise. In other words, the value of the dollar in foreign exchange markets will fall.

As this discussion indicates, exchange rate movements are not caused by relative changes in money stock growth rates, but by relative excesses of money growth above the amount demanded in each country. In attempting to determine if money growth has had an impact upon exchange rate movements, changes in the amount of money that people are willing to hold (that is, the demand for money) are critical. For example, the amount of money people are willing to hold will increase if real income rises, if interest rates fall, or if future inflation is expected to decline. There is no reason to expect that the amount of money that people are willing to hold will be the same in all comtries or that it changes at the same rate in all countries. 8 Therefore, there is no reason to expect relative money stock growth rates to equal relative excess money stock growth rates.

As shown in Table II, money stock growth abroad has been generally faster than that in the United States since late 1976. For example, between fourth quarter 1976 and mid-1978, the money stock has grown at a 12.1 percent annual rate in Germany and a 9.3 percent rate in Switzerland. Over the same period, the U.S. money stock increased at an 8.1 percent rate. Yet between fourth quarter 1976 and second quarter 1978, the value of the dollar in terms of the German mark and Swiss frane declined 16 and 27.5 percent, respectively. While changes in the demand for money are difficult to measure, the monetary in-

\footnotetext{
SSee, for example, Michel I. Hamburger, "The Demand for Money in an Open Eomomy: Gemany and the United Kingdom, Joumal of Monetow Leonomies (January 1977), pp.
} 


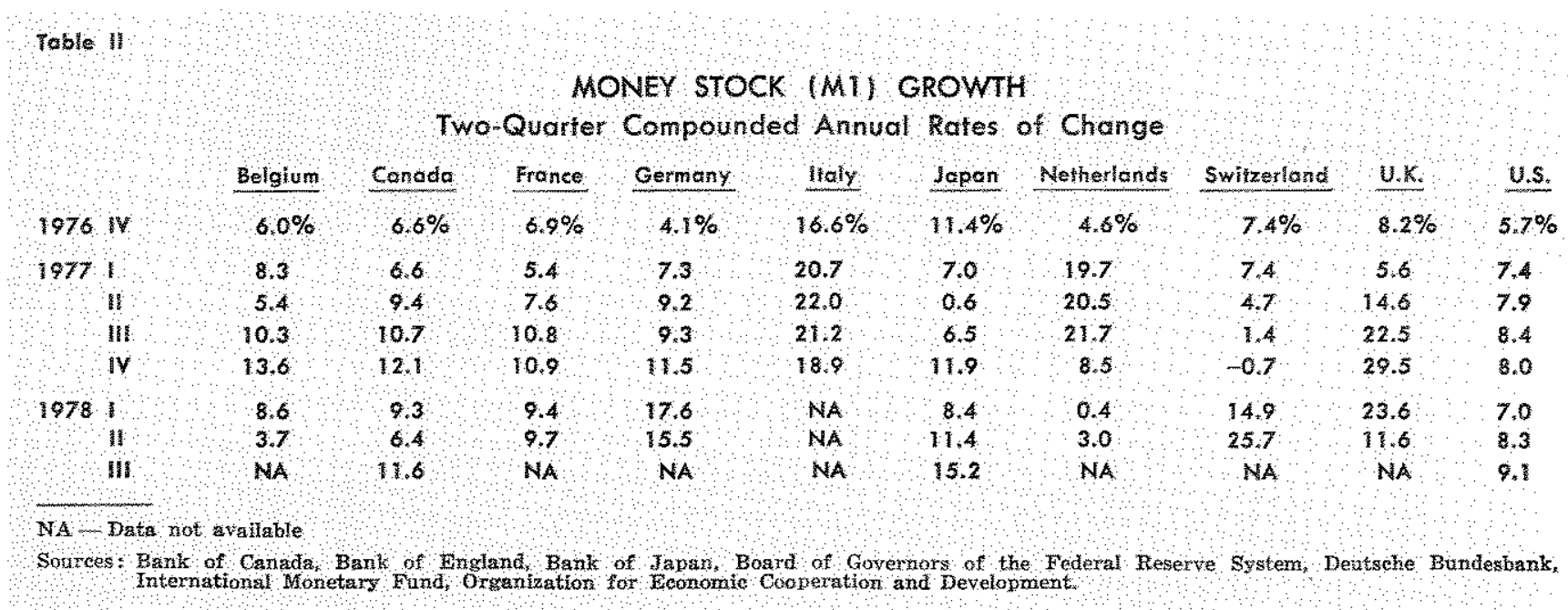

terpretation of price determination implies that the rate of inflation in each country can be used to indicate the rate of excess money growth. 9

\section{Exchange hates and Imbion Diferentals}

As shown in Chart 1 , exchange rate movements since the beginning of 1975 generally have been in the appropriate direction to offset changes in relative inflation rates. ${ }^{10}$ Over the $1975-76$ period, U.S. inflation, in general, decelerated relative to inflation abroad and the foreign exchange value of the dollar generally increased over this period. In the two cases where U.S. inflation accelerated relative to that abroad, the foreign exchange value of the dollar behaved in the ex-

For a discussion of the monetary interpretation of inflation, see Denis S. Kamosky, "The Link Between Money and Prices - 1971-76," this Review (June 1976), pp. 17-23.

Changes in the demand for money explain why money growth abroad can exceed U.S. money growth without producing an appreciation of the dollar. Expectations can significantly influence exchange rates in the short run. Suppose inflation is expected to accelerate in the United States but not in Germany and Switzerland. This could cause a decline in the demand for dollars and a corresponding increase in the demand for marks and francs. If the supply of dollars on foreign exchange markets is not sufficiently reduced, the dollar will depreciate against the mark and franc.

10For another discussion of this point and a critical look at the monetary approach see Stein, "The Mystery of the Declining Dollar," pp. 3-5.

The relationship between inflation differentials and exchange rates is not exact, especially in the short run. For example, the existence of nontradable goods and services, transportation and brokerage costs, barriers to trade and capital flows, expectations, and government intervention in foreign exchange markets prevent changes in rates of relative inflation from being perfectly reflected in changes in exchange rates. Further, turning points in exchange rate movements and changes in relative rates of inflation can be expected to differ somewhat; excess money growth affects inflation over time, while exchange rates respond more quickly to monetary disturbances. See lacob A. Frenkel, "Purchasing Power Parity: Doctrinal Perspective and Evidence from the 1920s; Journal of International Economics (May 1978), pp. 181-88. pected manner. U.S. inflation was accelerating relative to Swiss inflation over the $1975-76$ period and the value of the dollar in terms of the Swiss franc declined. U.S. inflation also accelerated relative to Canadian inflation between mid-1975 and mid-1976 and the U.S. dollar depreciated in terms of the Ca. nadian dollar during this period.

There is a case, however, in which changes in the foreign exchange value of the dollar and the rate of U.S. inflation relative to inflation abroad do not appear to be in offsetting directions. Over the 1975-76 period, U.S. inflation accelerated relative to inflation in the United Kingdom; however, the value of the dollar in terms of the British pound did not decline. In this case, the actions of national governments appear to have had a significant impact upon exchange rate movements over the 1975-76 period. During this period, there were substantial sales of British pounds by national govermments, thereby contributing to sig. nificant downward pressure on the foreign exchange value of the British pound."1

Since late 1976 , however, U.S. inflation has in general accelerated relative to inflation abroad and the foreign exchange value of the dollar has, on balance, declined since then. In the one case where U.S. inflation has decelerated relative to inflation abroad, Canada, the foreign exchange value of the U.S. dollar has steadily risen.

The pattern of relative rates of inflation, in most cases, showed a reversal around late 1976 . The most obvious cases are those involving the European countries. For example, consumer prices in the United

11Oficial sterling claims on the United Kingdom declined about 60 percent from 1974 to 1976 . See International Monetary Fund, Annual Report 1978 , p. 53. 


\section{Relative Rates of Inflation* and Movements in Exchange Rates}
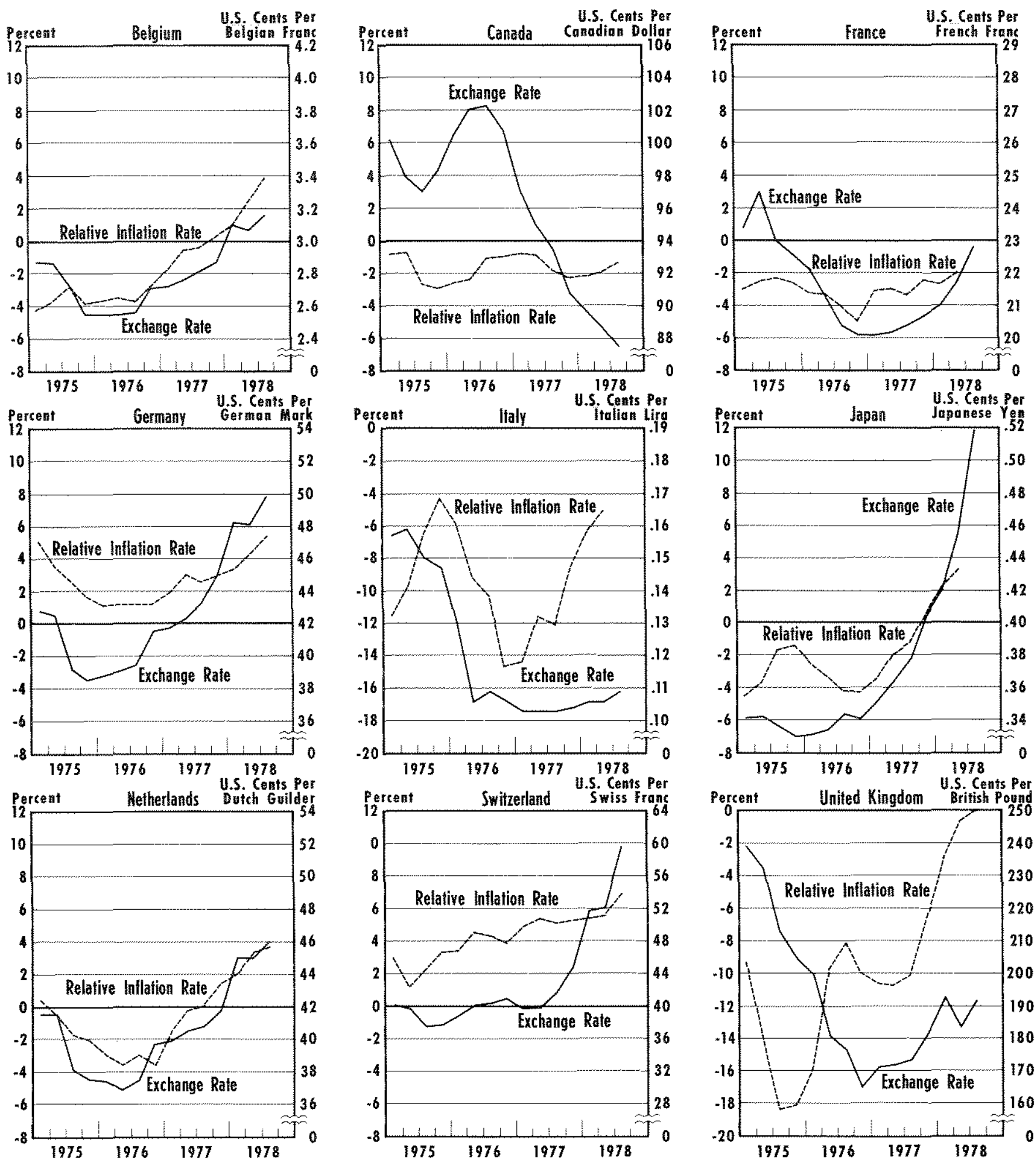

$1976 \quad 1977$ Sayces: International Monetary Fund. U.S. Department of Commerce, and Baord of Goyernars of the Fedefal Reserve Systert * Comparison of retes of change in consumer price index ovez corresponding fout quatter periads. Example: the U.S. Belgitsm relative intlatian fate for $1 / 77$ is

compuled by subtrating the percentage change in the Belgian CPl over the $1 / 76.1 / 77$ period from the percentage change in the U.S. CPl over the 3 ame four-quarter period. CPA data are seasonolly odjusted.

Eatest data plofted: Exchange fate for all countries-3ad quorter, relotive inflation eate for France, Itoly, and Japan-2nd quarter; other countriesußrd quarier.

Page 6 
States increased at a 5.9 percent rate between first quarter 1975 and fourth quarter 1976. The corresponding rates of inflation for six European countries were: Belgium (9.1 percent), France (9.6 percent), Germany ( 4.7 percent), Italy ( 15.7 percent), Netherlands ( 8.9 percent), Switzerland (2.1 percent), and the United Kingdom (19.3 percent). Since fourth quarter 1976, however, U.S. inflation has accelerated to a 7.6 percent rate. In contrast, inflation in the European countries has decelerated: Belgium ( 5.3 percent), France (9.2 percent), Germany (3.2 percent), Italy (13.8 percent), Netherlands (5.0 percent), Switzerland ( 1.5 percent), and the United Kingdom ( 10.9 percent). In short, the monetary view of exchange rate changes is consistent with the experience shown in Chart I.

\section{SUMMARY}

When exchange rate movements are viewed as basically monetary phenomena, the declining foreign exchange value of the dollar can be attributed to an excessive growth of the money stock in the United States relative to the monetary actions of other countries. Relative rates of economic growth, operating through the demand for money, do have an impact on the foreign exchange market. As real income grows, the quantity of money demanded increases. If the quantity of money demanded in the United States exceeds the amount supplied, all other factors constant, the foreign exchange value of the dollar would rise. Thus, a relatively rapid rate of U.S, economic growth, if not resulting from monetary stimulus, contributes to upward (rather than downward) pressure on the foreign exchange value of the dollar.

However, other factors, such as expectations of future accelerations in the rate of inflation, can cause a reduction in the quantity of money demanded. The interaction of money stock growth and changes in the demand for money is indicated by changes in the rate of inflation. The decline in the foreign exchange value of the dollar since late 1976 corresponds with an acceleration in U.S. inflation relative to inflation abroad.

The cause of both the relative acceleration in U.S. inflation and the corresponding decline in the foreign exchange value of the dollar are responses to relatively more expansionary (or less restrictive) monetary policies in the United States than abroad. The future course of the foreign exchange value of the dollar depends fundamentally upon the success of U.S. monetary policy in reducing the rate of inflation in the United States relative to the future performance of inflation in other countries.

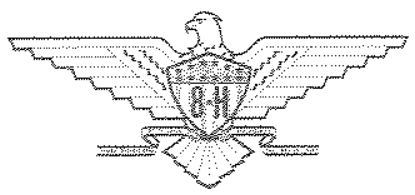

